\title{
PEMETAAN EKOSISTEM PADANG LAMUN BERESOLUSI TINGGI DENGAN METODE CLOSE RANGE PHOTOGRAMMETRY
}

\section{HIGH RESOLUTION SEAGRASS ECOSYSTEM MAPPING USING CLOSE RANGE PHOTOGRAMMETRY METHOD}

\author{
Muhammad Arif Nasution', Alaudin ${ }^{2}$, Muhammad Agam Thahir ${ }^{3}$ \\ ${ }^{1}$ Prodi Sumber Daya Akuatik, Fakultas Perikanan dan Ilmu Kelautan, Universitas Teuku Umar, \\ Aceh. \\ ${ }^{2}$ Prodi Ilmu Kelautan, Fakultas Perikanan dan Ilmu Kelautan, Universitas Teuku Umar, Aceh. \\ ${ }^{3}$ Prodi Perikanan, Fakultas Perikanan dan Ilmu Kelautan, Universitas Teuku Umar, Aceh.
}

Korespondensi: arifnasution@utu.ac.id

\begin{abstract}
Several remote sensing methods using satellite imagery and acoustic instruments have often been used in mapping aquatic ecosystems but expensive and need hight expertise. This method used in this study is quite new in mapping aquatic ecosystems, but has often been done in mapping terrestrial areas. This method produces clear high-resolution digital data using optical devices with high efficiency. This research was carried out in Pulau Matahari, Kepualauan Banyak, Aceh Singkil for 3 (three) months in the field and 2 (two) months of data processing. This research data is in situ primary data taken by taking optical images continuously from the surface of the water by swimmer using a waterproof digital camera and then processed with PhotoScan software. The results of this study are high-resolution digital image data that can be used to make seagrass ecosystems map at the study site, assess ecosystem status, identify seagrass species ( 4 species), density (St1:103,9 ind $/ \mathrm{m}^{2}$ and St2:128 ind// $\mathrm{m}^{2}$ ) and seagrass cover $(57 \%-61 \%)$.
\end{abstract}

Keywords : Mapping, Seagrass, Aquatic ecosystem

\section{Pendahuluan}

Padang lamun merupakan salah satu dari ekositem perairan laut dangkal yang tersebar luas di daerah tropis, sub tropis. Padang lamun dianggap sebagai salah satu ekosistem laut yang paling produktif dan kompleks dimana produktivitas lamun dibatasi oleh ketersedian hara. (Newmaster et al., 2011) Lamun terdiri dari kelompok kecil 66 spesies (Ruíz et al., 2009) yang membentuk padang lamun yang luas di semua wilayah pesisir bumi .

Kawasan Perairan Indonesia memiliki 15 jenis, yang terdiri atas 2 suku dan 7 marga. Jenis lamun yang dapat dijumpai adalah 12 jenis, yaitu Enhalus acoroides, Cymodocea rotundata, C. serrulata, Halophila decipiens, H. ovalis, H. minor, $H$. spinulosa, Haludole pinifolia, Halodule uninervis, Syringodium isoetifolium, Thalassia hemprichii, dan Thalassodendron ciliatum. Tiga jenis lainnya, yaitu Halophila sulawesii merupakan jenis lamun baru yang ditemukan pada tahun 2007 (Hernawan, 2017), Halophila becarii yang ditemukan herbariumnya tanpa 
keterangan yang jelas, dan Ruppia maritima yang dijumpai koleksi herbariumnya dari Ancol-Jakarta dan Pasir Putih Jawa Timur .

Padang lamun merupakan ekosistem yang sangat penting dalam menjaga keseimbangan ekosistem di perairan Padang lamun memegang peranan penting sebagai tempat mencari makan, berkembang biak, tempat asuhan dan tempat berlindung bagi hewan laut, dan subsratnya sebagai habitat organisme bentik (Komatsu, 2012). Dibandingkan dengan mangorove dan terumbu karang, ekosistem lamun mungkin kurang mendapat perhatian ilmiah (Torre-Castro, 2014) apalagi dalam hal pemetaan.

\section{Permasalahan}

Memetakan kondisi ekosistem pesisir menggunakan citra satelit bagus untuk area yang luas, tetapi memiliki beberapa keterbatasan jika kita ingin mendapatkan informasi detail tentang kondisi dasar laut. Sulit untuk menafsirkan dari citra satelit, karena keterbatasan gelombang elektromagnetik untuk menembus air laut hingga ke dasar dasar laut. Pada bidang biologi perikanan, close range photogrammetry acapkali dilakukan pada hal spesifik seperti halnya membuat model tiga dimensi (3D)( Figueira et al., 2015) dari karang sehingga sifat-sifat biofisiknya struktural dapat dikuantifikasi.

Untuk mengatasi kelemahan dari pengolahan data citra satelit dan mengadopsi teknik photogrammetry yang sudah dilakukan pada terumbu karang maka pada penelitian ini akan diterapkannya pada lamun, selain itu metode ini juga cukup sederhana tetapi menghasilkan data beresolusi tinggi yang jelas dengan efisiensi tinggi.

\section{Tujuan Khusus}

Tujuan dari penelitian ini adalah memetakan padang lamun dengan metode dan teknik yang cukup sederhana, tidak membutuhkan biaya dan keahlian yang tinggi.

\section{Urgensi Penelitian}

Sebagai salah satu ekosistem yang tidak kalah produktifnya dengan ekosistem mangrove dan terumbu karang tetapi yang paling kurang mendapatkan perhatian ilmiah, sehingga dengan adanya penelitian ini dapat menarik para peneliti ataupun mahasiswa yang ingin meneliti ojek lamun khususnya dalam hal pemetaan.

\section{Metode Penelitian}

\section{Waktu dan Tempat}

Penelitian ini dilaksanakan pada bulan Juli - Nopember 2019. Survey lapangan dilakukan di Pulau Matahari, Kepulauan Banyak Aceh Singkil, pada kedalam $0.5-3 \mathrm{~m}$, dengan 2 stasiun survey berkuran $40 \mathrm{~m}$ sejajar garis pantai dan 10 tegak lurus garis pantai. Penenetuan stasiun survey berdasarkan kondisi fisik perairan seperti kecerahan, pola arus dan keberadaan vegetasi lamun . 


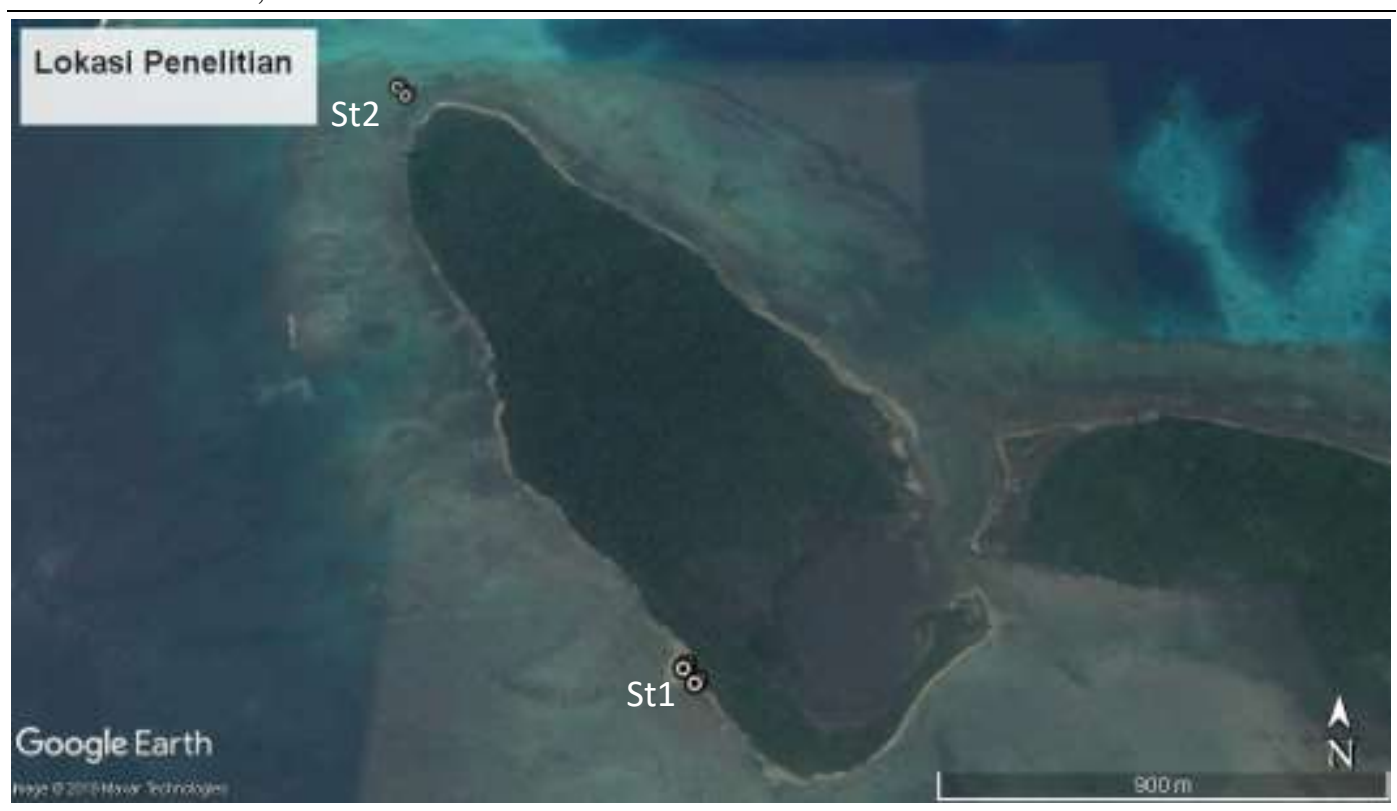

Gambar 1. Lokasi Stasiun Penelitian

Stasiun satu berjarak 10 meter dan Stasiun 2 berjarak 80 meter dari garis pantai surut terendah dengan koordinat $2^{\circ} 16^{\prime} 48.03^{\prime \prime} \mathrm{N}, 97^{\circ} 15^{\prime} 12.57^{\prime \prime} \mathrm{E}$ dan $2^{\circ} 16^{\prime} 46.76^{\prime \prime}$ $\mathrm{N}, 97^{\circ} 15^{\prime} 13.12^{\prime \prime} \mathrm{E}$.

\section{Alat dan Bahan}

Alat yang digunakan pada penelitian ini adalah kamera digital (Coolpix W300 Nikkon), GPS, Snorkel, Fin, Swimsuit, pelampung, Transek Kuadrat 1 x 1 m (Pipa Parlon), Meteran, Penggaris, Meteran, Papan kalibrasi, PhotoScan Agisoft, secchi disk, Tali Nylon, Personal Kumputer. Bahan yang dipakai adalah data foto.

\section{Pengumpulan Data}

Pengambilan foto menggunakan mode continuous shooting, pengambilan foto dilakukan dikeseluruhan luasan stasiun, pengambilan foto dilakukan pada cuaca yang cerah dengan arah arus yang stabil, pengambilan foto dapat dihentikan apabila ada perubahan arus yang menyebabkan gerakan rebahan daun lamun berubah arah, dan adanya pergeserangan banyangan yang cukup besar. Selama proses pengambilan foto antara satu foto dengan foto selanjutnya harus tumpang tindih sebesar $60 \%$. Pola pengambilan gambar dilakukan dengan pola zig zag mendekati garis pantai dan kemuadian menjauhi garis pantai dan sesterusnya, sampai keseluruh luasan stasiun.

\section{Pengamatan Lamun}

Pengamatan lamun secara manual perlu dilakukan guna proses validasi yang akan dilakukan dengan analisi deskriptif, Pengamatan lamun dilakukan dengan metode Seagrass Watch dengan parameter yang diamati meliputi kerapatan dan penutupan jenis lamun. Pada setiap stasiun dibuat tiga transek garis sepanjang 20 $\mathrm{m}$ tegak lurus garis pantai dengan jarak tiap transek $5 \mathrm{~m}$. Pada tiap transek garis diletakkan transek kuadrat $1 \mathrm{~m}$ x $1 \mathrm{~m}$ untuk mengamati kerapatan jenis dan 
penutupan lamun. Pengamatan pada transek dilakukan pada titik $0 \mathrm{~m}, 10 \mathrm{~m}$, dan $20 \mathrm{~m}$. Tata letak transek pengamatan lamun dijabarkan pada Gambar 2.

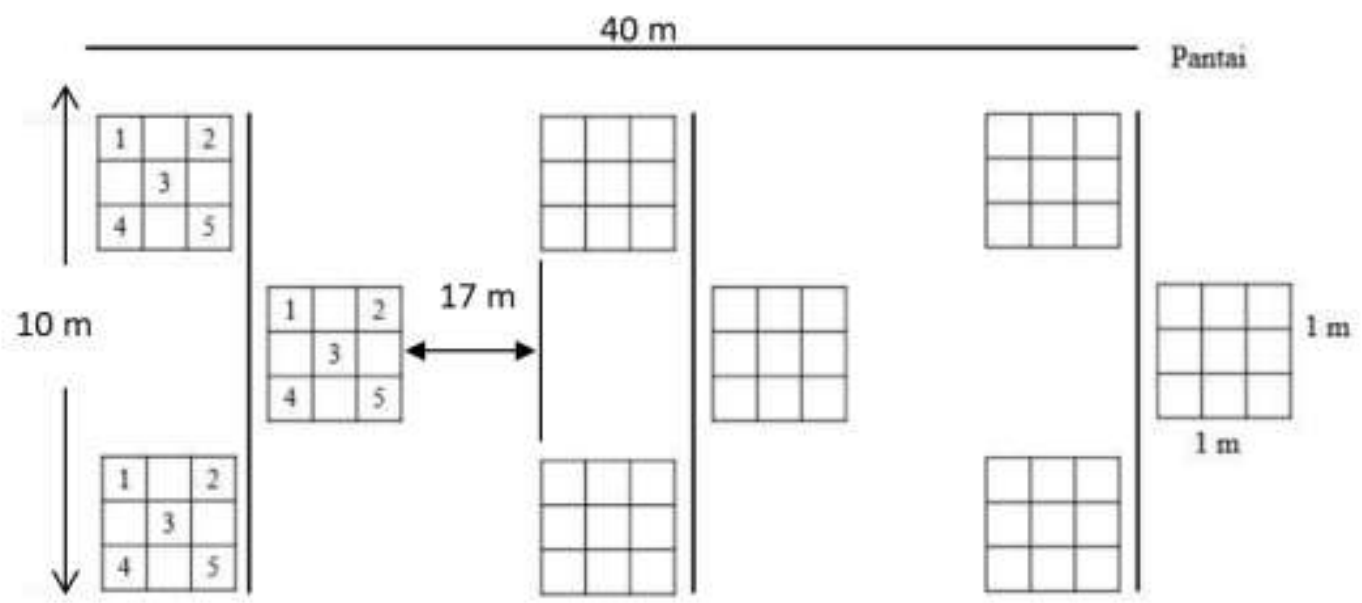

Gambar 2. Tata Letak Transek Pengamatan Lamun

\section{Analisis Data}

Kerapatan jenis lamun adalah jumlah tegakan dari suatu spesies persatuan luas tertentu. Kerapatan jenis pada setiap stasiun dihitung menggunakan rumus

$$
\mathrm{D}_{\mathrm{i}}=\frac{\mathrm{N}_{\mathrm{i}}}{\mathrm{A}}
$$

Keterangan:

$\mathrm{D}_{\mathrm{i}} \quad=$ Kerapatan jenis ke-i (ind $\left./ \mathrm{m}\right)$

$\mathrm{Ni}_{\mathrm{i}} \quad=$ Jumlah total individu jenis ke-i (ind)

A = luas area total pengambilan contoh (m)

Persentase penutupan jenis lamun yaitu luasan area yang tertutupi oleh tumbuhan lamun. Penutupan lamun ditentukan berdasarkan rumus:

$$
\mathrm{C}=\frac{\Sigma \mathrm{C}_{\mathrm{i}}}{\mathrm{N}}
$$

Keterangan:

$\mathrm{C} \quad=$ Penutupan jenis ke-i (\%)

$\mathrm{C}_{\mathrm{i}} \quad=$ Persentase penutupan jenis lamun ke-i pada tiap plot $(\%)$

$\mathrm{N} \quad=$ Jumlah plot yang ditemukan lamun jenis ke-i

Pengolahan Data Digital 


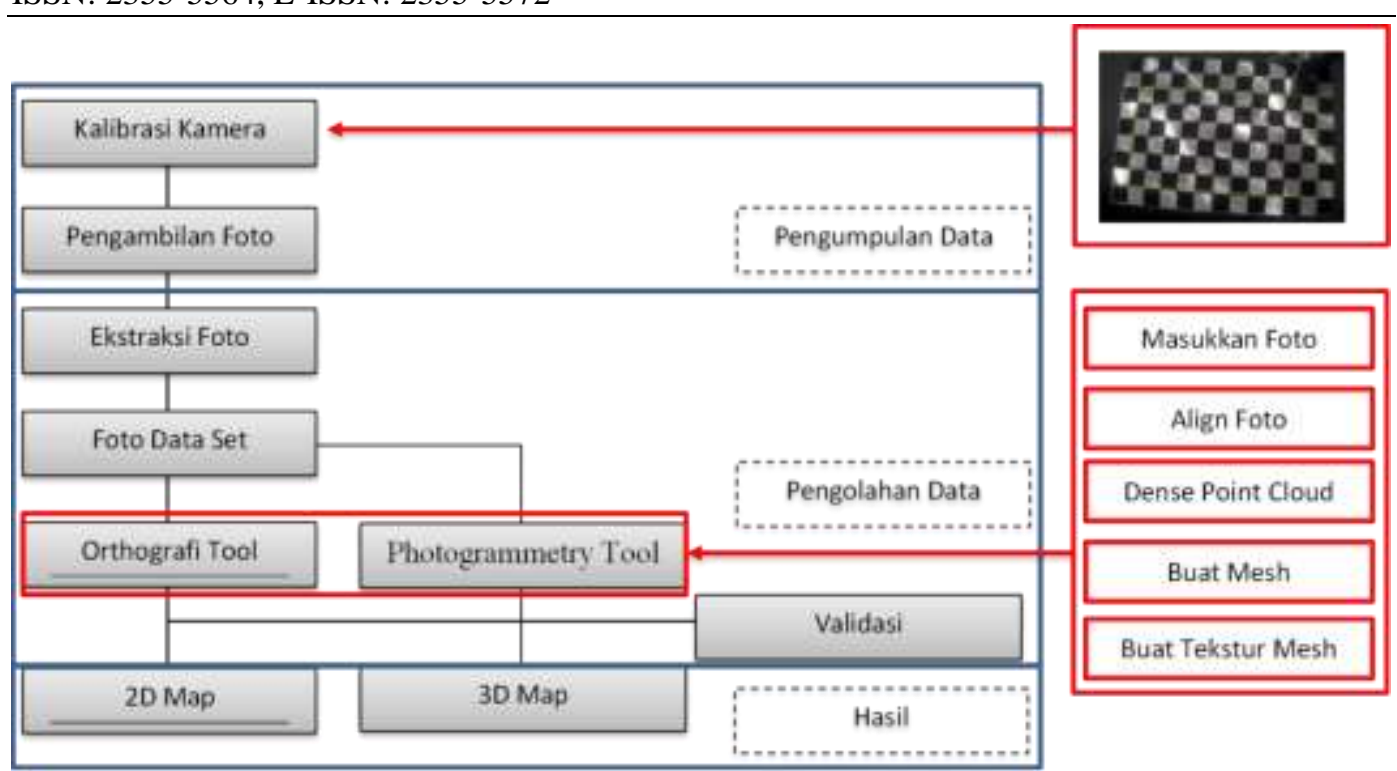

Gambar 3. Alur Pengolahan Data Digital

\section{Hasil dan Pembahasan}

\section{Kondisi Vegetasi Lamun}

Kondisi vegetasi lamun di stasiun satu terdiri dari 3 spesies yaitu Enhalus acoroides, Cymodocea rotundata dan Halodule pinifolia. Kondisi substrat dasar periran pasir berlumpur dan pasir berbatu pecahan karang.
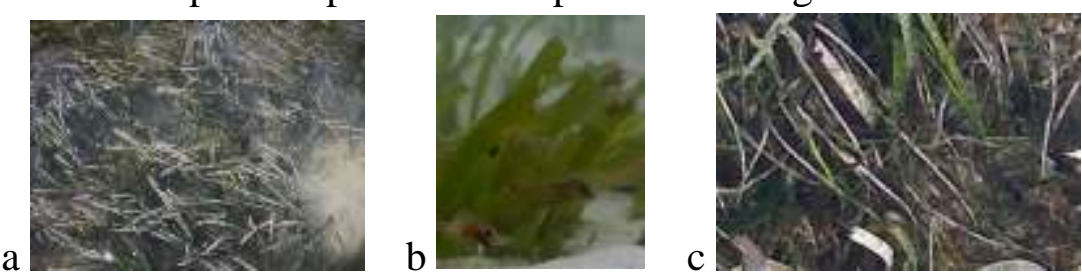

Gambar 4. Spesies vegetasi lamun di stasiun 1 ( a. Enhalus acoroides, b. Cymodocea rotundata, c. Halodule pinifolia).

Kondisi vegetasi lamun di stasiun dua hanya ditumukan satu spesies vegetasi lamun yaitu Thalassia hemprichii. Kondisi substrat dasar periran pasir berbatu pecahan karang.

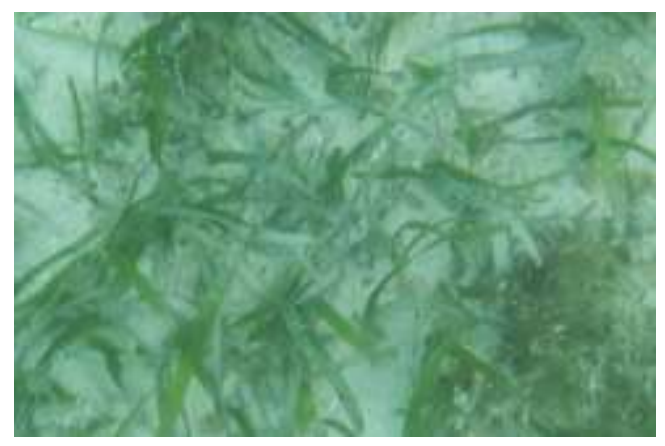

Gambar 5. Thalassia hemprichii

Nainggolan (2011) mengatakan lamun dapat tumbuh di daerah pasang surut terbuka serta perairan pantai yang berupa lumpur, pasir, kerikil dan patahan 
karang mati hingga kedalaman $4 \mathrm{~m}$. Spesies Enhalus acoroides hidup pada substrat lumpur, pasir berlumpur dan pada substrat pasir yang bercampur dengan pecahan karang. Spesies Cymodocea rotundata hidup pada substrat pasir atau pasir berlumpur. Spesies Halophila ovalis dapat hidup pada beragam substrat, baik berupa lumpur, pasir berlumpur, ataupun pecahan karang mati. Sedangkan Thalassia hemprichii hidup pada substrat pasir yang bercampur dengan pecahan karang.

\section{Kerapatan Jenis}

Kerapatan jenis lamun merupakan jumlah tegakan dari suatu spesies per satuan luas tertentu. Kerapatan jenis dapat dipengaruhi oleh ukuran daun dan letak pertumbuhan daun (Grech et al, 2012). Selain ukuran daun, jumlah tegakan lamun juga dapat mempengaruhi nilai kerapatan lamun di suatu perairan.

Tabel 1. Kerapatan jenis lamun

\begin{tabular}{llll}
\hline No & Spesies & Stasiun 1 $\left(\mathrm{ind} / \mathrm{m}^{2}\right)$ & Stasiun 2 $\left(\mathrm{ind} / \mathrm{m}^{2}\right)$ \\
\hline 1 & Enhalus acoroides & 50,2 & 0 \\
2 & Cymodocea rotundata & 30.4 & 0 \\
3 & Halodule pinifolia & 23.3 & 0 \\
4 & Thalassia hemprichii & 0 & 128 \\
\hline Total & & 103.9 & 128 \\
\hline
\end{tabular}

Kerapatan total lamun tertinggi ada pada Stasiun 2 dengan nilai sebesar 128 ind $/ \mathrm{m}^{2}$, sedangkan kerapatan total terendah berada di Stasiun 1 sebesar 103.9 ind $/ \mathrm{m}$.

\section{Tutupan Jenis dan Status Ekosistem}

Tutupan lamun menggambarkan luas daerah yang tertutupi oleh lamun. Faktor yang mempengaruhi nilai tutupan lamun adalah kerapatan dan morfologi jenis lamun (Jackson et al., 2001).

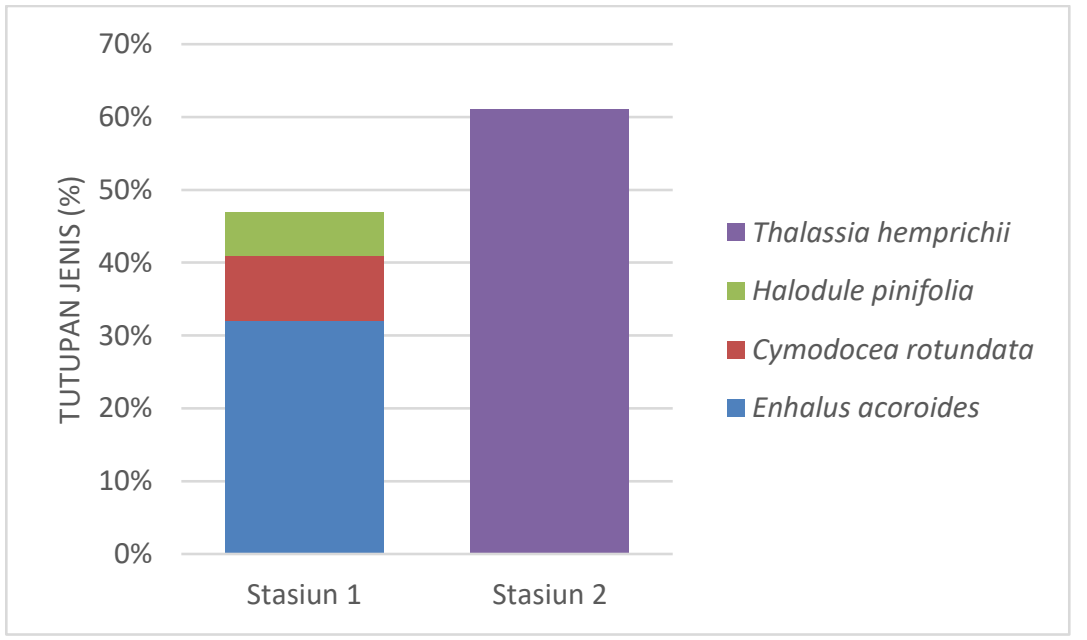

Gambar 6. Persentase tutupan jenis lamun di setiap stasiun 
Thalassia hemprichii tutupan tertinggi dibandingkan dengan jenis vegetasi lamun lainnya yaitu sebesar $61 \%$ dan hanya terdapat pada stasiun 2, 3 jenis lamun lainnya hanya terdapat pada stasiun 2 dengan nilai tutupan : Enhalus acoroides (32\%), Cymodocea rotundata (9\%) dan Halodule pinifolia (6\%). Status ekosistem lamun ditentukan berdasarkan persentase tutupan lamun (Brower et al., 1990), $\leq 5 \%$ buruk, 5\%-25\% kurang sehat, $25 \%-50 \%$ sehat, $50 \%-75 \%$ baik. $\geq$ $75 \%$ sangat baik.

\section{Analisis Data Digital}

Digital Surface Model

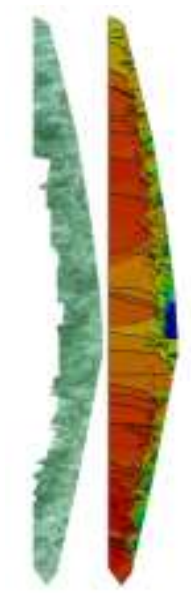

Gambar 7. Orthomosaic dan corresponding sparse Digital Surface Model (DSM) sebelum pengolahan

Data digital yang didapatkan pada saat turun lapangan sebanyak 1308 image, setelah dilakukan analisis DSM hanya 652 image dan 856 keypoint yang dapat diproses, hal ini disebabkan oleh perubahan bayangan tidak selaras dengan posisi kamera pada saat pengambilan data digital dilapangan. Adapun posisi kamera dapat dilihat pada tabel berikut :

Tabel 2. Posisi mutlak kamera

\begin{tabular}{|l|l|l|l|l|l|l|l|l|l|}
\hline & $\mathrm{X}[\mathrm{m}]$ & $\mathrm{Y}[\mathrm{m}]$ & $\mathrm{Z}[\mathrm{m}]$ & $\begin{array}{l}\text { Omega } \\
\text { [degree] }\end{array}$ & $\begin{array}{l}\text { Phi } \\
\text { [degree] }\end{array}$ & $\begin{array}{l}\text { Kappa } \\
\text { [degree] }\end{array}$ & $\begin{array}{l}\text { Camera } \\
\text { Displacement X [m] }\end{array}$ & $\begin{array}{l}\text { Camera } \\
\text { Displacement } \mathrm{Y}[\mathrm{m}]\end{array}$ & $\begin{array}{l}\text { Camera } \\
\text { Displacement Z [m] }\end{array}$ \\
\hline Mean & 0.564 & 0.546 & 1.324 & 0.327 & 0.216 & 0.093 & 0.062 & 0.055 & 0.117 \\
\hline Sigma & 0.102 & 0.094 & 0.239 & 0.014 & 0.023 & 0.006 & 0.010 & 0.015 & 0.037 \\
\hline
\end{tabular}




\section{Overlaping Image}

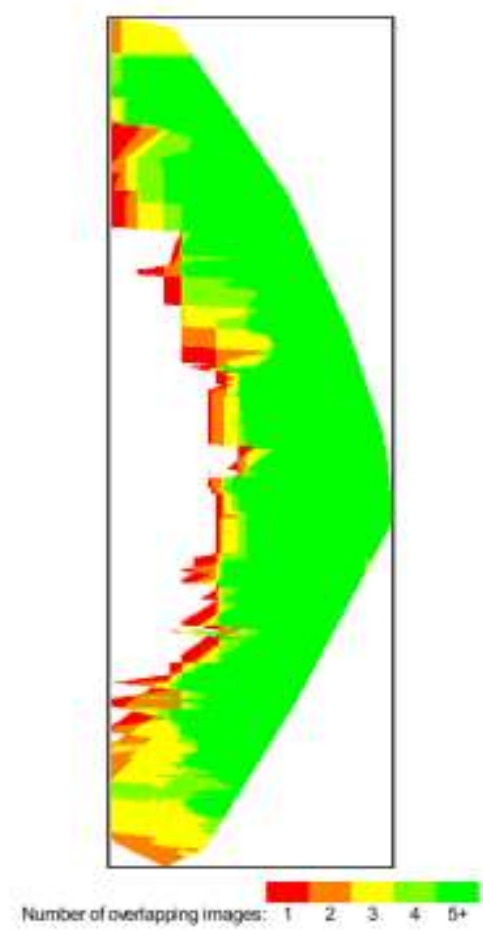

Gambar 8. Jumlah gambar yang tumpang tindih pada setiap pixel Orthomosaic

Area merah dan kuning menunjukkan tumpang tindih yang rendah sehingga hasil yang buruk dapat muncul. Area hijau menunjukkan tumpang tindih lebih dari 8 gambar untuk setiap pixel. Hasil kualitas yang baik akan dihasilkan selama jumlah pencocokan keypoint juga cukup pada suatu area ( 8 Gambar ) (lihat Gambar 8 untuk kecocokan keypoint).

Tabel 3. Paramter kamera

\begin{tabular}{|c|c|c|c|c|c|c|c|c|}
\hline & $\begin{array}{l}\text { Focal } \\
\text { Length }\end{array}$ & $\begin{array}{l}\text { Principal } \\
\text { Point } \mathrm{x}\end{array}$ & $\begin{array}{l}\text { Principal } \\
\text { Point y }\end{array}$ & $\mathrm{R} 1$ & $\mathrm{R} 2$ & R3 & $\mathrm{T} 1$ & $\mathrm{~T} 2$ \\
\hline $\begin{array}{l}\text { Initial } \\
\text { Values }\end{array}$ & $\begin{array}{l}2238.172 \\
\text { [pixel] } \\
4.300 \\
{[\mathrm{~mm}]}\end{array}$ & $\begin{array}{l}1632.000 \\
{[\text { pixel] }} \\
3.135 \\
{[\mathrm{~mm}]}\end{array}$ & $\begin{array}{l}1224.000 \\
{[\text { pixel] }} \\
2.352 \\
{[\mathrm{~mm}]}\end{array}$ & 0.000 & 0.000 & 0.000 & 0.000 & 0.000 \\
\hline $\begin{array}{l}\text { Optimized } \\
\text { Values }\end{array}$ & $\begin{array}{l}2957.654 \\
\text { [pixel] } \\
5.682 \\
{[\mathrm{~mm}]}\end{array}$ & $\begin{array}{l}1614.894 \\
\text { [pixel] } \\
3.103 \\
{[\mathrm{~mm}]}\end{array}$ & $\begin{array}{l}1190.351 \\
\text { [pixel] } \\
2.287 \\
{[\mathrm{~mm}]}\end{array}$ & 0.324 & 0.087 & 0.131 & $\begin{array}{l}- \\
0.005\end{array}$ & $\begin{array}{l}- \\
0.002\end{array}$ \\
\hline
\end{tabular}

Pengaturan kamera sangat berperan penting pada hasil analisis data, maka kamera perlu dioptimasi sehingga memperbesar persentase kecocokan antar gambar, adapun optimasi kamera yang dilakukan pada penelitian ini adalah optimasi focal range, point $\mathrm{X}$, dan point $\mathrm{Y}$, hasil optimasi akan mengubah distorsi 
radial $(\mathrm{R})$ dan distorsi tangen $(\mathrm{T})$, besaran perubahan nilai parametr awal kamera setelah dilakukan optimasi dapat dilhat pada tabel 3.

\section{Faktor kedalaman pengambilan data}

Kedalam pada stasiun penelitian berkisar antar 1,5 - 6 meter, dari hasil analisis didapati bahwa semakin dalam perairan maka semakin banyak kecocokan antar gambar, hal tersebut disebabkan karena semakin terbatasnya penetrasi sinar matahari seiring bertambahnya kedalaman yang menyebakan distorsi banyangan semakin samar, selain itu gelombang perairan juga berpengaruh terhadap kestabilan posisi pengambilan gambar.

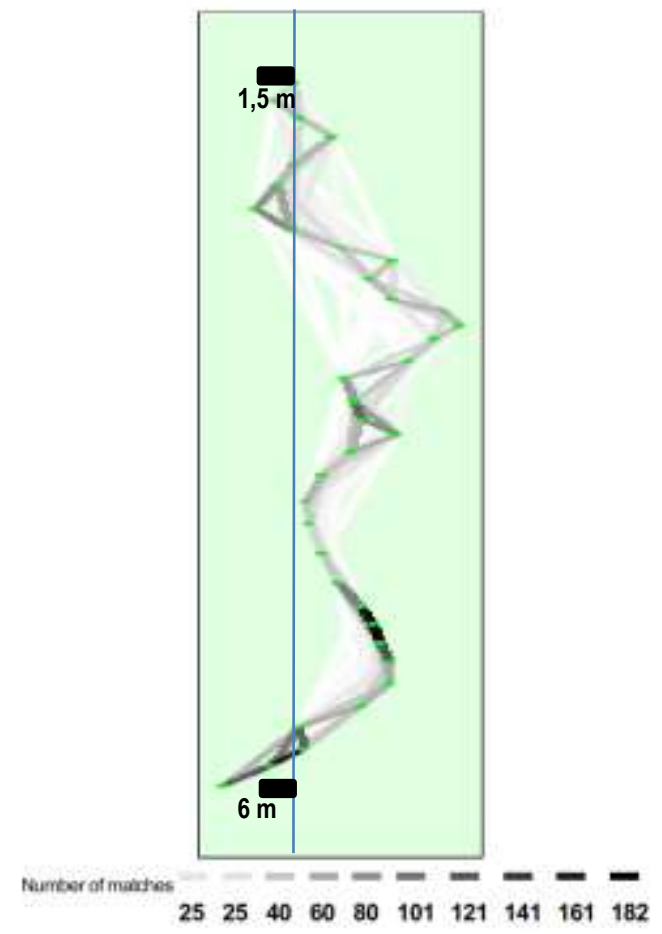

Gambar 9. Tautan 2D antara beberapa gambar yang seusai.

Gambar 9 menjelaskan bagaimana kedalam perairan mempengaruhi kecocokan antar gambar, dimana pada kedalam 1,5 m hanya terdapat 25 gambar yang cocok, kesesuain yang paling tinggi didapatkan pada kedalaman $6 \mathrm{~m}$ dimana terdapat 182 gambar yang sesuai. Semakin sesuai antar gambar maka semakin besar keypoint. 


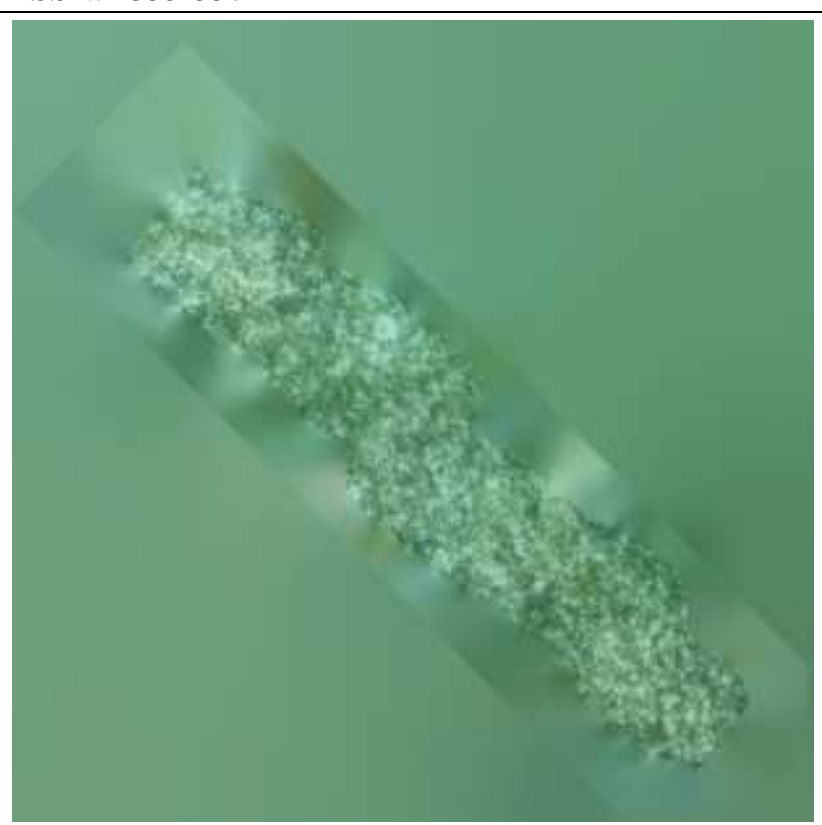

Gambar 7. Hasil rendering kontur vegetasi mangrove

Setelah dilakukan rendering dapat membentuk kontur seperti yang diamati dilapangan, resolusi yang dihasilkan juga tergolong tinggi yaitu $1 \mathrm{~cm}$, yang yang artinya pengamat dapat mengidentifikasi objek hanya dengan pembesaran gambar tanpa perlu pengolahan komposisi warna dan penggunaan algoritma.

\section{Kesimpulan dan Saran}

\section{Kesimpulan}

Berdasarkan hasil penelitian maka dapat disimpulkan.

1. Terdapat 4 Spesies yang teridentifikasi di lokasi peneltian yaitu Enhalus acoroides, Cymodocea rotundata, Halodule pinifolia dan Thalassia hemprichii.

2. Kerpatan jenis di lokasi penilitian $23,3-128 \mathrm{ind} / \mathrm{m}^{2}$, Tutupan jenis lamun berkisar $57 \%-61 \%$.

3. Jarak pengamat dengan vegetasi lamun sejauh 1,5 meter dan mengambil data sebanyak 1308 image, hanya $50 \%$ yang dapat diproses.

4. Gambar digital yang dihasilkan dapat mencapai resolusi $1 \mathrm{~cm}$.

\section{Saran}

1. Perlu dilakukan penelitian lebih lanjut melihat efsiensi dengan metode yang sama dengan penelitian ini tetapi dengan jarak pengamatan yang berbeda.

2. Dalam pengambilan data digital sebaiknya peneliti mempertimbangkan faktor kedalamn perairan, gelombang, arus dan perubahan bayangan.

\section{Daftar Pustaka}

Brower, J.E., J.H. Zar, and C.N. Von Ende. 1990. Field and Laboratory Methods for General Ecology. Wim. C. Brown Co. Pub.Dubuque. Iowa. 237 pp. 
de la Torre-Castro, M., Di Carlo, G., Jiddawi, N., 2014. Seagrass importance for a smallscale fishery in the tropics: the need for seascape management. Mar. Pollut. Bull. 83 (398-347).

Figueira, W., Ferrari, R., Weatherby, E., Porter, A., Hawes, S., \& Byrne, M. (2015). Accuracy and precision of habitat structural complexity metrics derived from underwater photogrammetry. Remote Sensing, 7, 16883-16900.

Grech, A., Chartrand-Miller, K., Erftemeijer, P., Fonseca, M., McKenzie, L., Rasheed, M., et al., 2012. A comparison of threats, vulnerabilities and management approaches in global seagrass bioregions. Environ. Res. Lett. 7, 024006.

Hernawan, U.E., Nurul, D., Sjafrie, M., Indarto, H., Supriyandi., Suyarso., Iswari, M.Y., Anggraini, K., Rahmat., 2017. Status Padang Lamun Indonesia. Pusat Penelitian Oseonografi. LIPI. Jakarta. $37 \mathrm{hlm}$.

Jackson, E.L., Rowden, A.A., Attrill, M.J., Bossey, S., Jones, M., 2001. The importance of seagrass beds as a habitat for fishery species. Oceanogr. Mar. Biol. 39, 269-304.

Komatsu T, Sagawa T, Sawayama S, Tanoue H, Mohri A, Sakanishi Y (2012) Mapping is a key for sustainable development of coastal waters: examples of seagrass beds and aquaculture facilities in Japan with use of ALOS images. In: Ghenai C (ed) Sustainable development. Intech Publishing Co, Rijeka, Croatia, pp 145-160

Newmaster, A.F., K.J. Berg, S. Ragupathy, M. Palanisamy, K. Sambandan, and S.G. Newmaster. (2011). Local knowladge and conservation of seagrass in the Tamil Nadu State of India. J. of Ethnobiology and Ethnomedicine. 37p.

Ruíz, J. M., Boudouresque, C. F., \& Enríquez, S. (2009). Mediterranean seagrasses. Botanica Marina, 52(5), 369-381. 